\title{
STUDIA PODYPLOMOWE NA UCZELNIACH TECHNICZNYCH - DOSTOSOWANIE OFERTY EDUKACYJNEJ DO POTRZEB RYNKU PRACY
}

\section{STUDIA PODYPLOMOWE JAKO FORMA KSZTAŁCENIA}

Studia podyplomowe jako forma kształcenia w ramach tradycyjnego podejścia należą do systemu edukacji formalnej, gdyż ich profil związany jest z regularną formą nauki, prowadzoną przez uprawnione do nauczania instytucje edukacyjne (przede wszystkim szkoły wyższe), a zajęcia odbywają się zgodnie z zatwierdzonymi programami nauczania. Ramy prawne dla studiów podyplomowych ustanowione są w Ustawie o szkolnictwie wyższym¹.

Jednakże w praktyce, zgodnie z wynikami badań uczestników tej formy kształcenia, jednym z ważnych motywów podejmowania studiów podyplomowych (podobnie jak studiów MBA - Master of Business Administration) jest nawiązywania relacji pozaformalnych, nawiązywanie kontaktów biznesowych i zdobywanie doświadczenia w wyniku rozmów z innymi uczestnikami studiów (networking)2 Biorąc powyższe trzeba zauważyć, że studia podyplomowe nie mieszczą się w ramach klasyfikacji jako kształcenie stricte formalne.

W chwili obecnej w Polsce nie funkcjonuje uregulowany prawnie system, w ramach którego można potwierdzać kwalifikacje zawodowe uzyskane na drodze pozaformalnej. Sejm VIII kadencji, w grudniu 2015 roku przyjął ustawę, która wprowadzi stosowne i jednoznaczne uregulowania m. in poprzez uruchomienie Zintegrowanego Rejestru Kwalifikacji. Konsekwencją tego będzie umiejscowienie systemu kształcenia nieformalnego i pozaformalnego w ramach systemu formalnego.

\footnotetext{
* Dr BARtosz SobotKa - Syntea SA, Lublin, e-mail: bartosz.sobotka@syntea.pl.

${ }^{1}$ Ustawa z dnia 27 lipca 2005 r. - Prawo o szkolnictwie wyższym; Dz.U. nr 164, poz. 1365 z późn. zm.

${ }^{2}$ I. Janiak-Rejno, Kształcenie ustawiczne słuchaczy studiów podyplomowych - wyniki badań empirycznych, „Edukacja ustawiczna dorosłych” 2009, nr 4(67), s. 50-57. http://www.mttp.pl/pobieranie/badanie_thinktank_mba.pdf; (dostęp 15.05.2016).
} 
Wszystkie formy kształcenia zatem wzajemnie na siebie oddziałują i wpływają na siebie nie tylko pod względem różnych klasyfikacji i definicji legalnych, ale także pod względem ich praktycznych aspektów, mających wspólny mianownik rozwój kapitału ludzkiego ${ }^{3}$.

W obszarze edukacji ma miejsce także zjawisko (proces) globalizacji, przybierając formę koncepcji edukacji globalnej. Definiuje się ją jako przekazywanie wiedzy w wymiarze globalnym oraz jako wielowymiarowe interdyscyplinarne podejście metodyczne do procesu uczenia się trwające całe życie zw. Lifelong Learning - LLL. Immanentną cechą tej koncepcji jest elastyczność dotycząca kształcenia i edukacji polegająca na tym aby człowiek sam mógł dostosowywać się do ciągłe zmieniających się warunków rynku pracy ${ }^{4}$, wynikających z nieustających zmian w otoczeniu społeczno-gospodarczym człowieka (postęp).

Zgodnie $\mathrm{z}$ koncepcją polityki unijnej w zakresie edukacji, uczenie się przez całe życie to klucz do społeczeństwa wiedzy, a społeczeństwo wiedzy odgrywa kluczową rolę w gospodarce i podejmowaniu decyzji społecznych. W komunikacie Komisji Europejskiej Making a European Area of Lifelong Learning a Reality uznano, że LLL opiera się na czterech wzajemnie zależnych i wspierających się celach: samorealizacja, bycie aktywnym obywatelem, integracja społeczna, zdolności adaptacyjne. Studia podyplomowe niewątpliwie wpisują się zatem w koncepcję LLL i stanowią ważny element (ilościowo) całokształtu form kształcenia dorosłych będących przedmiotem ogólnoeuropejskich badań w tym zakresie ${ }^{5}$.

Z kolei według metodyki Eurostatu wskaźnik LLL to udział osób w wieku 25 $\div 64$ lata, którzy pobierali naukę lub uczestniczyli w szkoleniu w ciągu 4 tygodni poprzedzających badanie. Analizując tak zdefiniowaną aktywność edukacyjną osób dorosłych, dostrzegamy bardzo duże dysproporcje pomiędzy krajami UE. Najwyższy wskaźnik LLL od wielu lat występuje w krajach skandynawskich (Dania, Szwecja

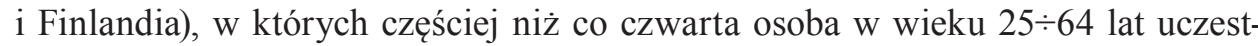
niczy w edukacji ustawicznej. Natomiast w wielu krajach, przeważnie z Europy Wschodniej oraz Grecji wskaźnik ten oscyluje wokół 3\%. W Polsce wynosi 4,0\%, co jest znacznie poniżej średniej europejskiej $(10,8 \%)^{6}$.

${ }^{3}$ Szerzej: Raport Agencji Wykonawczej ds. Edukacji, Kultury i Sektora Audiowizualnego (EACEA), Dorośli w systemie edukacji formalnej: polityka i praktyka w Europie, tłum. J. Czernik, Fundacja Rozwoju Systemu Edukacji, Warszawa 2011.

${ }^{4}$ S. Borkowska, Czy dyfuzja atypowych form zatrudniani jest warunkiem koniecznym do jego wzrostu? [w:] L. Frąckiewicz, A. Rączaszek (red.) Kapitał Społeczny, Katowice 2004. s. 287-288.

${ }^{5}$ Szerzej o koncepcji LLL w ramach polityki Unii Europejskiej i jej znaczenia dla kształcenia dorosłych w Polsce: J. Grotowska-Leder, Rzecz o kształceniu dorosłych. Lifelong learning w Polsce, w perspektywie Unii Europejskiej, ACTA UNIVERSITATIS LODZIENSIS, FOLIA SOCIOLOGICA 50, 2014 oraz A. Dziedziczak-Foltyn Lifelong learning jako niedoceniania w Polsce droga do społeczeństwa wiedzy, Serwis HR, Wolters Kluwer 2015.

${ }^{6}$ Dane Eurostat za 2014 rok. http://ec.europa.eu/eurostat/tgm/table.do?tab=table\&plugin=1\&language $=$ en\&pcode $=$ tsdsc440 (dostęp 15.05.2015). 
Jeżeli przyjęlibyśmy, że słuchaczami studiów podyplomowych są osoby powyżej 25 roku życia to w 2014 roku ok. 20\% osób dorosłych podnoszących swoje kompetencje (w ramach wskaźnika LLL dla Polski) było słuchaczami właśnie studiów podyplomowych, co jest znaczną wartością. Jest to oczywiście tylko szacunek, gdyż z uwagi na reformę szkolnictwa w Polsce i wprowadzenie systemu bolońskiego, uczestnikami studiów podyplomowych mogą być także osoby kończące pierwszy stopień (licencjat) w ramach szkolnictwa wyższego, a więc mogą mieć poniżej 25 lat. Ponadto pomimo faktu, że są one dedykowane dla osób chcących podnieść swoje kompetencje zawodowe w sposób świadomy, a więc w oparciu o już zdobyte doświadczenie zawodowe i autoanalizę potrzeb kompetencyjnych, wiele osób podejmuje decyzję o zapisie na studia podyplomowe równolegle kontynuując studia drugiego stopnia, traktując je jako formę specjalizacji lub rozszerzenia zakresu studiów.

Celem artykułu (i wykonanych badań własnych autora) jest analiza studiów podyplomowych, na przykładzie organizowanych przez uczelnie techniczne, i próba określenia czynników warunkujących zgodność oferty edukacyjnej uczelni (lub jednostek naukowych posiadających uprawnienia do ich prowadzenia) z potrzebami rynku pracy, stymulującej rozwój i efektywność gospodarki (realne korzyści dla rozwoju przedsiębiorstw) oraz zaspokojenie dążeń pracodawców i pracowników do podnoszenia kwalifikacji zawodowych.

\section{SKALA I ZAKRES STUDIÓW PODYPLOMOWYCH W POLSCE}

Transformacja systemowa w Polsce przyniosła także niebywały wzrost wskaźnika skolaryzacji netto społeczeństwa na poziomie uczelni wyższych z około $10 \% \mathrm{w}$ roku akademickim 1990/91 do około 39\% w roku akademickim 2012/2013. Gwałtowny wzrost liczby studentów na początku XXI w. związany był także ze zjawiskiem wyżu demograficznego przypadającego na lata 90 . XX wieku. Tabela nr 1 przedstawia liczbę studentów ogółem w wybranych latach w okresie 1990-2014 oraz liczbę studentów studiów podyplomowych (dane opracowano na podstawie danych GUS7).

\footnotetext{
${ }^{7}$ Szkoły wyższe i ich finanse, GUS 2008-2014.
} 
Tabela 1. Liczba studentów studiów I i II stopnia oraz studiów podyplomowych

\begin{tabular}{|l|c|c|c|c|c|c|c|c|c|}
\hline & $\mathbf{1 9 9 0 / 9 1}$ & $\mathbf{1 9 9 5 / 9 6}$ & $\mathbf{2 0 0 0 / 0 1}$ & $\mathbf{2 0 0 5} / \mathbf{0 6}$ & $\mathbf{2 0 0 8 / 2 0 0 9}$ & $\mathbf{2 0 1 0 / 1 1}$ & $\mathbf{2 0 1 2 / 1 3}$ & $\mathbf{2 0 1 3 / 1 4}$ & $\mathbf{2 0 1 4 / 1 5}$ \\
\hline $\begin{array}{l}\text { Liczba studen- } \\
\text { tów studiów } \\
\text { I i I stopnia } \\
\text { (A) }\end{array}$ & 403824 & 794642 & 1584804 & 1953832 & 1927762 & 1841251 & 1676927 & 1549877 & 1469386 \\
\hline $\begin{array}{l}\text { Liczba studen- } \\
\text { tów podyplomo- } \\
\text { wych (B) }\end{array}$ & 32809 & 56217 & 146750 & 135930 & 168438 & 185418 & 172670 & 163628 & 149799 \\
\hline $\begin{array}{l}\text { Studenci studiów } \\
\text { podyplomowych } \\
\text { uczelnie tech- } \\
\text { niczne (C) }\end{array}$ & 2047 & 5137 & 15811 & 11906 & 18828 & 18565 & 14279 & 12882 & 11425 \\
\hline $\begin{array}{l}\text { Stosunek (B) } \\
\text { do (A) }\end{array}$ & $8,12 \%$ & $7,07 \%$ & $9,26 \%$ & $6,96 \%$ & $8,74 \%$ & $10,07 \%$ & $10,30 \%$ & $10,56 \%$ & $10,19 \%$ \\
\hline $\begin{array}{l}\text { Stosunek (C) } \\
\text { do (B) }\end{array}$ & $6,24 \%$ & $9,14 \%$ & $10,77 \%$ & $8,76 \%$ & $11,18 \%$ & $10,01 \%$ & $8,27 \%$ & $7,87 \%$ & $7,63 \%$ \\
\hline
\end{tabular}

Źródło: Opracowanie własne na podstawie danych GUS.

Zgodnie z danymi z Tabeli 1 zauważalny jest wzrost liczby studentów studiów podyplomowych nie tylko w liczbach bezwzględnych do roku 2010 ale także w porównaniu do ogólnej liczby studentów. Świadczy to o popularyzacji tej formy kształcenia wśród osób dorosłych. Spadek liczby studentów studiów podyplomowych po 2010 roku jest ściśle powiązany z niżem demograficznym oraz faktem powolnego wygaszania unijnej perspektywy finansowej na lata $2007 \div 2013$, z której w ramach Programu Operacyjnego Kapitał Ludzki były finansowane studia podyplomowe, co powodowało, że studia te były bezpłatne dla słuchaczy.

Ponadto dane w Tabeli 1 wskazują na stosunek liczby studentów/słuchaczy studiów podyplomowych na uczelniach technicznych do ogólnej liczby słuchaczy studiów podyplomowych. Do 2010 roku można zaobserwować wzrost zainteresowania podyplomowymi studiami technicznymi, jako tymi, które cieszą się większym prestiżem oraz z uwagi na „przesyt” rynku osobami z kompetencjami humanistycznymi. Natomiast spadek liczby studentów po 2010 roku można między innymi tłumaczyć faktem wzrostu zainteresowania ofertą studiów I i II stopnia przez młodzież, a tym samym uczelnie techniczne nie były zainteresowane tworzeniem takiej oferty edukacyjnej jak studia podyplomowe (wzrost liczby studentów studiów technicznych przedstawia Tabela nr 2) $)^{9}$. Dane w Tabeli 2 odzwierciedlają też wyraźnie skutki niżu demograficznego, od 2012 roku.

81 W Polsce wprowadzono trzy stopniowy system studiów ustawa o szkolnictwie wyższym, która weszła w życie 1 września 2005 roku, zatem dane do tego roku nie uwzględniają tego podziału.

9 Wpływ na wzrost liczby studentów uczelni technicznych miał także wdrożony przez Ministerstwo Nauki i Szkolnictwa Wyższego program kierunków zamawianych oferujący stypendia dla studentów tych kierunków. 
Tabela 2. Wzrost liczby studentów studiów technicznych

\begin{tabular}{|l|c|c|c|c|c|c|c|}
\hline & $\mathbf{2 0 0 8 / 0 9}$ & $\mathbf{2 0 0 9 / 1 0}$ & $\mathbf{2 0 1 0 / 1 1}$ & $\mathbf{2 0 1 1 / 1 2}$ & $\mathbf{2 0 1 2 / 1 3}$ & $\mathbf{2 0 1 3 / 1 4}$ & $\mathbf{2 0 1 4 / 1 5}$ \\
\hline $\begin{array}{l}\text { Liczba studentów ogółem } \\
\text { I i II stopnia (A) }\end{array}$ & 1927762 & 1900014 & 1841251 & 1764060 & 1676927 & 1549877 & 1469386 \\
\hline $\begin{array}{l}\text { Liczba studentów studiów } \\
\text { technicznych (B) }\end{array}$ & 322111 & 317468 & 318738 & 337828 & 343083 & 331099 & 319019 \\
\hline Stosunek (B) do (A) & $16,71 \%$ & $16,71 \%$ & $17,31 \%$ & $19,15 \%$ & $20,46 \%$ & $21,36 \%$ & $21,71 \%$ \\
\hline
\end{tabular}

Źródło: Opracowanie własne na podstawie danych GUS.

Tabela 3 przedstawia liczbę studentów studiów podyplomowych w Polsce w roku akademickim 2014/2015 z podziałem na typy uczelni oraz podziałem na uczelnie publiczne i niepubliczne.

Tabela 3. Liczba studentów studiów podyplomowych w Polsce w roku akademickim 2014/2015 z podziałem na typy uczelni oraz podziałem na uczelnie publiczne i niepubliczne.

\begin{tabular}{|c|c|c|c|}
\hline & \multirow[t]{2}{*}{ Typ uczelni } & \multicolumn{2}{|c|}{ Słuchacze } \\
\hline & & ogółem & w tym kobiety \\
\hline \multirow[t]{3}{*}{$\mathrm{A}$} & Ogółem & 149799 & 104414 \\
\hline & Publiczne & 90113 & 57729 \\
\hline & Niepubliczne & 59686 & 46685 \\
\hline \multirow[t]{3}{*}{1.} & Szkoły wyższe & 120833 & 88108 \\
\hline & Publiczne & 61147 & 41423 \\
\hline & Niepubliczne & 59686 & 46685 \\
\hline \multirow[t]{3}{*}{1.1.} & Uniwersytety & 25477 & 20075 \\
\hline & Publiczne & 24814 & 19562 \\
\hline & Niepubliczne & 663 & 513 \\
\hline \multirow[t]{3}{*}{1.2.} & Wyższe szkoły techniczne & 11425 & 5516 \\
\hline & Publiczne & 11018 & 5310 \\
\hline & Niepubliczne & 407 & 206 \\
\hline \multirow[t]{3}{*}{1.3.} & Wyższe szkoły rolnicze & 4425 & 2663 \\
\hline & Publiczne & 4378 & 2646 \\
\hline & Niepubliczne & 47 & 17 \\
\hline 1.4. & Wyższe szkoły ekonomiczne & 28326 & 19388 \\
\hline
\end{tabular}




\begin{tabular}{|c|c|c|c|}
\hline & Typ uczelni & \multicolumn{2}{|c|}{ Sluchacze } \\
\hline & Publiczne & 9308 & 5716 \\
\hline & Niepubliczne & 19018 & 13672 \\
\hline \multirow[t]{3}{*}{1.5} & Wyższe szkoły pedagogiczne & 6169 & 5594 \\
\hline & Publiczne & 3291 & 2938 \\
\hline & Niepubliczne & 2878 & 2656 \\
\hline 1.6. & Uniwersytety medyczne & 2041 & 1790 \\
\hline 1.7. & Wyższe szkoły morskie & 35 & 24 \\
\hline 1.8. & Akademie wychowania fizycznego & 827 & 536 \\
\hline \multirow[t]{3}{*}{1.9.} & Wyższe szkoły artystyczne & 710 & 546 \\
\hline & Publiczne & 686 & 529 \\
\hline & Niepubliczne & 24 & 17 \\
\hline \multirow[t]{3}{*}{1.10.} & Wyższe szkoły teologiczne & 509 & 399 \\
\hline & Publiczne & 18 & 17 \\
\hline & Niepubliczne & 491 & 382 \\
\hline \multirow[t]{3}{*}{1.11.} & Pozostałe szkoły wyższe & 38648 & 31203 \\
\hline & Publiczne & 2490 & 1981 \\
\hline & Niepubliczne & 36158 & 29222 \\
\hline 1.12 . & Szkoły wyższe resortu obrony narodowej & 1287 & 204 \\
\hline 1.13. & Szkoły wyższe resortu spraw wewnętrznych & 954 & 170 \\
\hline 2. & Jednostki Polskiej Akademii Nauk & 610 & 353 \\
\hline 3. & Instytuty badawcze (inne niż PAN) & 392 & 172 \\
\hline 4. & Krajowa Szkoła Administracji Publicznej & 72 & 38 \\
\hline 5. & Centrum Medyczne Kształcenia Podyplomowego & 27892 & 15743 \\
\hline
\end{tabular}

Źródło: Opracowanie własne na podstawie danych GUS.

W roku akademickim 2014/2015 w Polsce na studiach podyplomowych studiowało około 150000 studentów. Według podziału na typy uczelni/jednostek edukacyjnych najliczniejsza ich grupa studiowała na uczelniach zaliczonych do „pozostałych szkół wyższych niepublicznych" - 36158 studentów. W ramach tego typu przeważają uczelnie prywatne niezaliczane do głównych typów (technicznych, ekonomicznych, artystycznych itp.). Druga pod względem liczebności grupa słuchaczy studiowała w Centrum Medycznym Kształcenia Podyplomowego, gdzie kształcą się lekarze i lekarze dentyści w ramach specjalizacji. Na kolejnych miejscach były: uniwersytety publiczne - 24814 studentów, niepubliczne wyższe szkoły uczelnie ekonomiczne - 19018 studentów i publiczne wyższe szkoły techniczne - 11018 studentów.

Natomiast wśród słuchaczy studiów podyplomowych w roku akademickim 2014/2015 największą popularnością, cieszyły się następujące kierunki: ekono- 
miczne i administracyjne - 37,1 tys. studentów; pedagogiczne - 37,3 tys. (w tym nauczycielskie - 23,3 tys.) studentów, medyczne - 33,2 tys. studentów. Natomiast w ramach kierunków oferowanych przez uczelnie techniczne były to następujące kierunki: inżynieryjno-techniczne 2,9 tys. studentów; architektura i budownictwo -1 tys. studentów.

Analizując powyższe dane można stwierdzić, że w przypadku tych grup zawodowych, tj. nauczycieli i lekarzy uczestnictwo w studiach podyplomowych jest warunkiem koniecznym rozwoju kariery i zdecydowana większość osób kontynuuje naukę w tych formach traktując tę edukację jako swoiste przedłużenie studiów I i II stopnia (lub jednolitych jak w przypadku medycyny). W przypadku wyboru kierunków ekonomicznych i administracyjnych słuchacze kierują się motywem nabycia kompetencji rynkowych ułatwiających im funkcjonowanie w otoczeniu gospodarczym. Z drugiej strony uczelniom najłatwiej jest przygotować ofertę w ramach tych kierunkach (ekonomicznych i administracyjnych) zarówno na uczelniach publicznych, jak i niepublicznych, gdyż kierunki te są najpopularniejsze wśród kandydatów na studia I i II stopnia, a niż demograficzny wymusza szukanie sposobów zapewnienia pensum dla kadry akademickiej.

Tabela 4. Podział studentów pod względem płci na poszczególnych typach studiów.

\begin{tabular}{|l|c|c|c|c|c|c|c|}
\hline & $\mathbf{2 0 0 8 / 2 0 0 9}$ & $\mathbf{2 0 0 9 / 1 0}$ & $\mathbf{2 0 1 0 / 1 1}$ & $\mathbf{2 0 1 1 / 2 0 1 2}$ & $\mathbf{2 0 1 2 / 1 3}$ & $\mathbf{2 0 1 3 / 1 4}$ & $\mathbf{2 0 1 4 / 1 5}$ \\
\hline $\begin{array}{l}\text { Liczba studentów I i II } \\
\text { stopnia ogółem (A) }\end{array}$ & 1927762 & 1900014 & 1841251 & 1764060 & 1676927 & 1549877 & 1469386 \\
\hline $\begin{array}{l}\text { Liczba kobiet studen- } \\
\text { tów I i II stopnia (B) }\end{array}$ & 1098351 & 1105442 & 1082483 & 1036155 & 985027 & 905032 & 853004 \\
\hline $\begin{array}{l}\text { Liczba studentów } \\
\text { studiów podyplomo- } \\
\text { wych (C) }\end{array}$ & 168438 & 194212 & 185418 & 189636 & 172670 & 163628 & 149799 \\
\hline $\begin{array}{l}\text { Liczba kobiet studentów } \\
\text { na studiach podyplomo- } \\
\text { wych (D) }\end{array}$ & 112013 & 132198 & 130024 & 133333 & 121741 & 113436 & 104414 \\
\hline $\begin{array}{l}\text { Liczba studentów } \\
\text { studiów podyplomowych } \\
\text { na uczelniach technicz- } \\
\text { nych (E) }\end{array}$ & 18828 & 20310 & 18565 & 17401 & 14279 & 12882 & 11425 \\
\hline $\begin{array}{l}\text { Liczba kobiet studentów } \\
\text { studiów podyplomo- } \\
\text { wych na uczelniach } \\
\text { technicznych (F) }\end{array}$ & 8431 & 9383 & 8713 & 8352 & 6901 & 6180 & 5516 \\
\hline Stosunek (C) do (A) & $8,7 \%$ & $10,2 \%$ & $10,1 \%$ & $10,7 \%$ & $10,3 \%$ & $10,5 \%$ & $10,2 \%$ \\
\hline $\begin{array}{l}\text { Stosunek (F) do (E) } \\
\text { (E) }\end{array}$ & $44,78 \%$ & $46,20 \%$ & $46,93 \%$ & $48,00 \%$ & $48,33 \%$ & $47,97 \%$ & $48,28 \%$ \\
\hline $\begin{array}{l}\text { Stosunek (D) do (C) } \\
\text { Stosunek (B) do (A) }\end{array}$ & $56,50 \%$ & $68,07 \%$ & $70,12 \%$ & $70,31 \%$ & $70,51 \%$ & $69,33 \%$ & $69,70 \%$ \\
\hline
\end{tabular}

Źródło: Opracowanie własne na podstawie danych GUS. 
Ilustracja graficzna danych z Tabeli 4 lepiej odwzorowuje dysproporcje w ich wartościach (rys. 1).

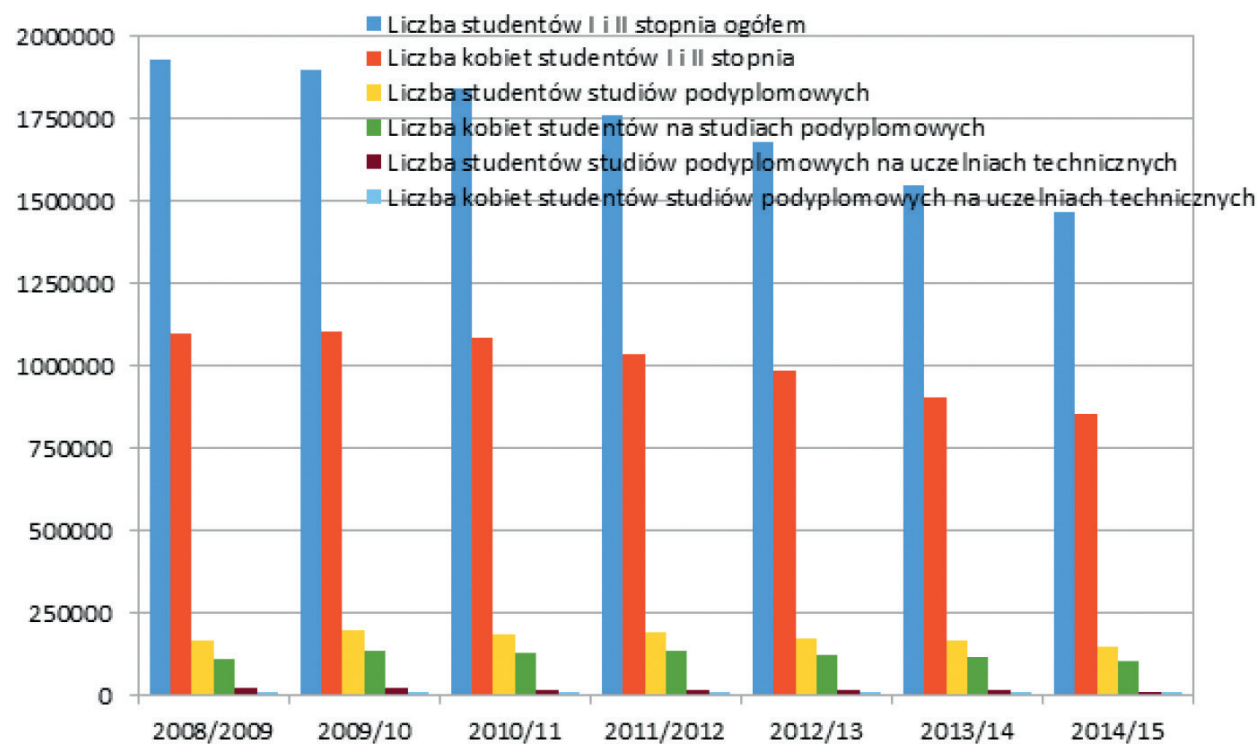

Rys. 1. Liczba uczestników studiów podyplomowych. Źródło: Opracowanie własne na podstawie danych GUS

Zgodnie z danymi z Tabeli 4 obserwuje się przewagę liczby kobiet w stosunku do liczby mężczyzn zarówno na studiach I i II stopnia, jak i na studiach podyplomowych, przy czym dysproporcja na korzyść kobiet w przypadku studiów podyplomowych jest znaczna. Niewątpliwie na zjawisko to mają wpływ zmiany kulturowe zachodzące we współczesnym świecie i zmiany ról w życiu społecznym. Coraz więcej kobiet aktywnie uczestniczy w życiu zawodowym, a studia są niewątpliwie przepustką do kariery. W przypadku studiów podyplomowych ponad $70 \%$ udział kobiet w ogólnej licznie słuchaczy studiów podyplomowych może wpisywać się w ten trend społeczny w aspekcie chęci przebicia tzw. „szklanego sufitu”, przez kobiety, czyli zrównania się z mężczyznami zarówno w zarobkach, jak i dostępie do kierowniczych stanowisk zdominowanych przez mężzzyzn ${ }^{10}$.

W przypadku liczby kobiet na studiach podyplomowych oferowanych przez uczelnie techniczne tradycyjnie jest ona niższa aniżeli liczba mężczyzn, jednakże widać trend wzrostu liczby kobiet, co zapewne jest powiązane ze zjawiskiem opi-

${ }^{10}$ Szerzej na temat zjawiska: B. Budrowska, "Szklany sufit”, czyli co blokuje kariery kobiet, Kultura i Historia nr 6/2004 http://www.kulturaihistoria.umcs.lublin.pl/archives/158, (dostęp 16.05.2016). 
sanym powyżej, jak i szeregiem kampanii skierowanych w celu zachęcania kobiet do podejmowania studiów technicznych ${ }^{11}$.

Warto zauważyć, że liczba uczestników studiów podyplomowych w stosunku do liczby studentów ogółem I i II stopnia oscyluje około 10\%.

Ponadto można dokonać podziału liczby studentów studiów podyplomowych na uczelniach technicznych ze względu na status uczelni: publiczna i niepubliczna. W ramach tego podziału zdecydowanie przeważają uczelnie publiczne, na które przypada około $95 \%$ studentów ${ }^{12}$.

\section{ANALIZA TWORZENIA OFERTY EDUKACYJNEJ NA STUDIACH PODYPLOMOWYCH NA UCZELNIACH TECHNICZNYCH - BADANIE WŁASNE}

Studia podyplomowe jako forma kształcenia formalnego są uregulowane w polskim systemie prawnym, gdzie ustawodawca pozostawia dużą autonomię samym uczelniom. Władze uczelni na podstawie wewnętrznych procedur - regulaminów uruchamiania studiów podyplomowych w dowolny sposób regulują ich zakres merytoryczny, jakość oraz formę.

Przedmiotem badania opisanego w niniejszej pracy jest analiza oferty studiów podyplomowych uruchomianych przez uczelnie techniczne w aspekcie oczekiwań rynku pracy i dostosowanie do faktycznych potrzeb pracodawców. Badania kwestionariuszowe objęły 37 edycji studiów podyplomowych oferowanych w roku akademickim 2014/2015 i semestrze zimowym roku akademickiego 2015/2016. Ankiety nadesłano z 16 kierunków studiów na 10 wydziałach 9 uczelni. Badania prowadzone były od października 2015 roku do stycznia 2016 roku.

Celem badania było ustalenie motywów uruchomiania studiów podyplomowych przez poszczególne jednostki uczelni technicznych w kontekście ich dostosowania do realnych potrzeb rynku pracy.

Na pytanie dotyczące bezpośrednich motywów przygotowanie oferty dydaktycznej respondenci udzielali następujących odpowiedzi (Tabela 5).

${ }^{11}$ Szerzej na temat tego zjawiska w: Raporcie „Kobiety na politechnikach 2016”, Fundacja Edukacyjna Perspektywy, Marzec 2016. http://dziewczynynapolitechniki.pl/2015/images/dla-mediow/ raport-kobiety-napolitechnikach-2016.pdf; (dostęp 16.05.2016).

12 Szkoły wyższe i ich finanse w 2014 rok, GUS s. 159. 
Tabela 5. Motywy zorganizowania studiów podyplomowych (oferty wydziału/jednostki)

\begin{tabular}{|c|l|c|c|}
\hline Lp. & Motyw & $\begin{array}{c}\text { Liczba } \\
\text { odpowiedzi } \\
\text { pozytywnych }\end{array}$ & $\begin{array}{c}\text { Udział \% odpowiedzi } \\
\text { w badanych ofertach } \\
\text { studiów }\end{array}$ \\
\hline 1 & $\begin{array}{l}\text { Możliwości sfinansowania ze środków unijnych } \\
\text { oferty edukacyjnej }\end{array}$ & 2 & $5 \%$ \\
\hline 2 & $\begin{array}{l}\text { Kompetencje pracowników naukowych } \\
\text { jednostki/wydziału }\end{array}$ & 19 & $51 \%$ \\
\hline 3 & $\begin{array}{l}\text { Zgłoszone zapotrzebowanie konkretnego } \\
\text { przedsiębiorstwa (sformalizowane umowy } \\
\text { o współpracy) }\end{array}$ & 15 & $40 \%$ \\
\hline 4 & $\begin{array}{l}\text { Uzupełnienie kompetencji zawodowych, spowo- } \\
\text { dowane koniecznością uzyskania certyfikatu/ } \\
\text { uprawnień do działalności w danym zawodzie }\end{array}$ & 23 & $62 \%$ \\
\hline 5 & $\begin{array}{l}\text { Uzupełnienie pensum godzinowego } \\
\text { pracowników naukowo-dydaktycznych }\end{array}$ & 0 & 0 \\
\hline 6 & Inne & 5 & $14 \%$ \\
\hline
\end{tabular}

Źródło: Opracowanie własne - ankietowani mogli wskazać więcej niż jedną odpowiedź.

W 40\% przypadków przygotowanie studiów podyplomowych było odpowiedzią na potrzeby rynku pracy, co wydaje się poziomem niesatysfakcjonującym. Pomimo ani jednej odpowiedzi na pytanie 5, przy ponad 50\% odpowiedzi na pytanie 2 można stwierdzić, że przygotowanie oferty studiów podyplomowych miało charakter podażowy a nie popytowy, tj. związana była z realnymi zasobami kadrowymi uczelni, a nie z rzeczywistymi potrzebami rynku pracy. Natomiast ponad $60 \%$ odpowiedzi na pytanie 4 jest ściśle powiązane z wysokim poziomem reglamentacji polskiej gospodarki, co nie koniecznie musi mieć odzwierciedlenie w faktycznych potrzebach kompetencyjnych rynku pracy. W przypadku odpowiedzi na pytanie 6, najczęstszymi odpowiedziami były: możliwość uzyskania dofinasowania ze środków unijnych oraz inicjatywa pracowników naukowych wydziału. To ostatnie często jednak związane jest z motywem 4 w sensie uzyskania dodatkowych źródeł finansowych dla pracowników i wydziału. Stawki godzinowe za prowadzenie zajęć na studiach podyplomowych są zdecydowanie wyższe niż wynagrodzenie pracowników dydaktycznych uczelni (np. za tzw. nadgodziny), zwłaszcza na studiach finansowanych ze środków unijnych. Inicjatywa pracowników naukowo-dydaktycznych uczelni do uruchomiania studiów podyplomowych z danej tematyki wynika także z chęci kształcenia - przekazania nowoczesnej wiedzy z tematyki wykraczającej poza realizowany program kształcenia.

Powyższa interpretacja została potwierdzona także w pytaniu dotyczących sposobu dotarcia do potencjalnych słuchaczy. W 15 przypadkach była to oferta 
dedykowana do konkretnych przedsiębiorstw, pokrywa się z odpowiedziami na pytanie 3 z Tabeli 5. Natomiast w pozostałych przypadkach oferta ta była otwarta, czyli skierowana do szerokiego ogółu potencjalnych słuchaczy.

Na pytanie dotyczące sposobów finasowania uczestnictwa udzielane były następujące odpowiedzi (Tabela 6).

Tabela 6. Źródła finasowania uczestnictwa w studiach podyplomowych

\begin{tabular}{|l|c|c|}
\hline Sposób finasowania & $\begin{array}{c}\text { Liczba odpowiedzi } \\
\text { pozytywnych }\end{array}$ & $\begin{array}{c}\text { Udział \% odpowiedzi w badanych } \\
\text { ofertach }\end{array}$ \\
\hline Fundusze unijne & 3 & $8 \%$ \\
\hline $\begin{array}{l}\text { Pracodawca (w tym } \\
\text { w części) }\end{array}$ & 10 & $27 \%$ \\
\hline Uczestnicy & 30 & $81 \%$ \\
\hline
\end{tabular}

Źródło: Opracowanie własne.

W przypadku pytania dotyczącego sposobów finasowania uczestnictwa w studiach podyplomowych odpowiedzi wskazują, w zdecydowanej większości przypadków, na uczestników jako finansujących studia. W 7 przypadkach wskazano na przedsiębiorstwa, co nie pokrywa się z odpowiedzią na pytanie 3 z Tabeli 5 .

Spośród liczby 37 studiów podyplomowych przygotowanych przez poszczególne wydziały/jednostki uruchomianych zostało tylko 24, czyli co trzecie studia nie zostały uruchomiane $\mathrm{z}$ uwagi na małe zainteresowanie kandydatów, a zatem rynku.

Skład kadry dydaktycznej, prowadzącej zajęcia na badanych studiach przedstawia tabela 7.

Tabela 7. Pytanie dotyczące kadry dydaktycznej na oferowanych studiach podyplomowych

\begin{tabular}{|l|c|}
\hline Kadra dydaktyczna & Liczba odpowiedzi \\
\hline Pracownicy naukowi wydziału & 37 \\
\hline Pracownicy naukowi innych wydziałów uczelni & 25 \\
\hline Pracownicy naukowi innych uczelni & 14 \\
\hline Zagraniczni pracownicy naukowi & 0 \\
\hline Osoby niezwiązane z uczelnią - eksperci/pracownicy przedsiębiorstw & 33 \\
\hline
\end{tabular}

Źródło: Opracowanie własne.

W ramach odpowiedzi na pytanie dotyczące zaangażowania osób niezwiązanych z uczelnią w około $90 \%$ przypadków stwierdzono ten fakt. Świadczy to 
o zjawisku wykorzystywania wiedzy i umiejętności osób z dużym doświadczeniem praktycznym, pracujących w przedsiębiorstwach o wysokim poziomie organizacyjnym, wykorzystujących najnowsze osiągnięcia technologiczne i techniczne, rzeczoznawców, ekspertów. Taki model oferty uczelni, łączący teorię z praktyką należy uznać za bardzo pożądany, podnoszący poziom jakości kształcenia w jego aspekcie aplikacyjnym. Odpowiedzi wskazują także na znaczący udział kadry dydaktycznej z innych wydziałów danej uczelni $-68 \%$ oraz z innych uczelni $-38 \%$, co jest przejawem współpracy środowisk naukowych. Natomiast brak w badanej próbie wykładowców z zagranicy, świadczy o niskim stopniu internacjonalizacji uczelni w kontekście możliwości, jakie stwarzają ramy programu Erasmus, jak i ogólnopolskiemu trendowi zabiegania uczelni o studentów z zagranicy.

Kolejna tabela przedstawia odpowiedzi na pytanie dotyczące udziału procentowego kadry dydaktycznej przewidzianej do prowadzenia zajęć na studiach podyplomowych.

Tabela 8. Zatrudnienie kadry dydaktycznej przewidzianej do prowadzenia zajęć na studiach podyplomowych.

\begin{tabular}{|l|c|}
\hline Struktura składu kadry dydaktycznej & Średni procentowy udzial \\
\hline Pracownicy naukowi wydziału & $47,1 \%$ \\
\hline Pracownicy naukowi innych uczelni & $20,1 \%$ \\
\hline $\begin{array}{l}\text { Osoby niezwiązane z uczelnią - eksperci/pracownicy } \\
\text { przedsiębiorstw }\end{array}$ & $35 \%$ \\
\hline
\end{tabular}

Źródło: Opracowanie własne.

Dane z Tabeli 8 potwierdzają dane z Tabeli 7, tj. obrazują zaangażowanie prawie w połowie przypadków kadry z macierzystego wydziału/jednostki w zakresie struktury procentowej kadry dydaktycznej na oferowanych studiach podyplomowych. Dane z powyższej tabeli prezentują satysfakcjonujący poziom osób niezwiązanych z uczelnią jako kadry dydaktycznej.

W Tabeli 8 przedstawiono odpowiedzi na pytanie dotyczące struktury zajęć.

Tabela 8. Udział zajęć w programie studiów prowadzonych w formie zajęć praktycznych

\begin{tabular}{|l|c|}
\hline Struktura zajęć & $\begin{array}{c}\text { Średni procentowy udzial } \\
\text { w ogólnej strukturze }\end{array}$ \\
\hline Zajęcia realizowane w przedsiębiorstwach & $4,5 \%$ \\
\hline $\begin{array}{l}\text { Zajęcia prowadzone w formie warsztatów i zajęć praktycznych na } \\
\text { uczelni }\end{array}$ & $47,8 \%$ \\
\hline
\end{tabular}

Źródło: Opracowanie własne. 
Powyższe dane wskazują na bardzo niski poziom procentowego udziału zajęć realizowanych w przedsiębiorstwach, a więc $\mathrm{w}$ realnym środowisku biznesowym. Wynika to jednak $z$ faktu, że interesariusze zewnętrzni tj. pracodawcy słuchaczy studiów podyplomowych, nawet gdy biorą czynny udziału w organizacji takich studiów i choć często mają infrastrukturę do zajęć praktycznych (maszyny, urządzenia, programy komputerowe, stanowiska produkcyjne) na wyższym poziomie technicznym niż uczelnie to jednak jej nie udostępniają z uwagi na brak wypracowanych mechanizmów z uczelnią.

Pomimo tego, na uwagę zasługuje wysoki udział procentowy zajęć prowadzonych $\mathrm{w}$ formie zajęć praktycznych - ćwiczeń laboratoryjnych i projektowych Taka forma zajęć pozwala na pozyskiwanie przez uczestników studiów umiejętności praktycznych, pożądanych na rynku pracy zwłaszcza zatrudniających osoby z kompetencjami inżynierskimi ${ }^{13}$.

Na pytanie dotyczące zaangażowania się interesariuszy zewnętrznych tzn. przedsiębiorców, organizacji zawodowych w proces opracowywania programu kształcenia studiów podyplomowych w badanej próbie, uzyskano następujące odpowiedzi: w 66\% przypadków interesariusze brali udział w opracowaniu efektów kształcenia dla danego programu, w $64 \%$ przypadków brali udział w opracowywaniu planu studiów i w 45\% przypadków brali udział w opracowaniu kart przedmiotowych, czyli sylabusów. W celu dostosowanie oferty edukacyjnej do potrzeb rynku pracy poziom zaangażowania interesariuszy zewnętrznych powinien być jeszcze wyższy i sięgać nawet $100 \%$. Potwierdzeniem takiej potrzeby i zależności jest korelacja studiów podyplomowych uruchomianych z tymi, przy których tworzeniu programu kształcenia, miało miejsce wysokie zaangażowanie interesariuszy zewnętrznych.

W przeważającej większości badanych ofert, organizatorzy studiów podyplomowych nie monitorują losów absolwentów.

\section{PODSUMOWANIE I WNIOSKI}

Studia podyplomowe w Polsce stanowią istotną pozycję w zakresie oferty dydaktycznej dla kształcenia osób dorosłych (kształcenie ustawiczne). Wyniki badań własnych pokrywają się w części z wynikami badań przeprowadzonych w projekcie „Knowledge@Work zintegrowany model kształcenia przez całe życie na uczelniach wyższych", realizowanego w ramach Poddziałania 4.1.1.: Wzmocnienie potencjału dydaktycznego uczelni. Wskazały one na: brak podejścia strategicznego do formy kształcenia podyplomowego, niewłaściwy sposób podejmowania decyzji odnośnie

${ }^{13}$ Patrz: Rozporządzeie MNiSW z 2.11.2011r. w sprawie KRK dla Szkolnictwa Wyższego, D.U.11.253.1520 
oferty studiów, brak koordynacji, brak jednolitych zasad tworzenia programów, intuicyjne budowanie oferty, bez poparcia w odpowiednich badaniach rynku jako stanowiące najważniejsze obszary problemowe oraz utrudnienia, które mogą mieć wpływ na organizację i rozwój studiów podyplomowych w przyszłości ${ }^{14}$.

$\mathrm{Z}$ uwagi na stopień zaawansowania procesów technologicznych we współczesnym świecie studia podyplomowe na uczelniach technicznych mają szczególne znaczenia w zakresie przygotowywania kadr na potrzeby rynku pracy. Wyniki badań przedstawionych $\mathrm{w}$ niniejszej pracy wskazują na niedostateczne przygotowanie oferty edukacyjnej na potrzeby rynku pracy (niski stopień współpracy z interesariuszami zewnętrznymi przy tworzeniu oferty edukacyjnej). Potwierdzeniem tej tezy jest fakt uruchomiania studiów podyplomowych w tych przypadkach, gdzie korelacja ta była wysoka.

Należy zauważyć (i potwierdzają to przeprowadzone badania), że uczelnie techniczne i poszczególne wydziały oferują wiele studiów podyplomowych, o różnej, bardzo interesującej tematyce, ważnej z punktu rozwoju wiedzy i technologii, które $\mathrm{z}$ braku dostatecznego zainteresowania nie zostają nigdy uruchomione, $\mathrm{z}$ uwagi na fakt że zgłasza się zbyt mała liczba słuchaczy, aby zapewnić samofinansowanie się studiów.

Cieszą się powodzeniem przede wszystkim takie studia, które kończą się uzyskaniem certyfikatów niezbędnych do uprawiania zawodu lub prowadzenia określonej działalności zawodowej lub takie, które finansowane są przez delegujące swoich pracowników przedsiębiorstwa. Ustawa o deregulacji zawodów przyczyniła się do zmniejszenia zainteresowania niektórymi, cieszącymi się wielkim powodzeniem, studiami podyplomowymi, np. z tematyki zarządzania nieruchomościami, audytów energetycznych.

Dlatego też dobór tematyki studiów podyplomowych, efektów kształcenia jakie słuchacz studiów podyplomowych może osiągnąć, zwłaszcza w zakresie umiejętności, ale też i wiedzy, ma znaczenie kluczowe. Ważna jest współpraca z przedsiębiorstwami, możliwość wykorzystania ich infrastruktury technicznej, o poziomie przewyższającym $\mathrm{w}$ wielu przypadkach posiadaną przez uczelnie, do prowadzenia zajęć praktycznych.

W celu dostosowania oferty edukacyjnej studiów podyplomowych do faktycznych potrzeb rynku pracy bardzo istotna jest analiza potrzeb kompetencyjnych rynku pracy realizowana poprzez audyt kompetencyjny w przedsiębiorstwach ${ }^{15}$, nawiązywanie i utrzymywania stałej współpracy ze środowiskiem biznesowym przez uczelnie w kontekście procesów dydaktycznych, zaangażowanie praktyków do tworzenia programów nauczania w ramach studiów podyplomowych, jak

${ }^{14}$ J. Poteralski, Ogólnopolskie badania na grupie osób odpowiedzialnych za studia podyplomowe, Szczecin, czerwiec 2013.

${ }^{15}$ Przykładem narzędzia stosowanego jako audyt kompetencji może być usługa oferowana przez Syntea SA jako wsparcie procesów zatrudnienia: http://syntea.pl/media/materialy/Syntea_przedsiebiorstwa.pdf. 
i prowadzenia zajęć w formie warsztatowej, w tym w przedsiębiorstwach, co powinno mieć swoje odzwierciedlenie w poszczególnych regulaminach dotyczących uruchomiania studiów podyplomowych na uczelniach jako warunki konieczne ${ }^{16}$.

Powierzanie prowadzenie zajęć na studiach podyplomowych osobom związanym z przemysłem, doświadczonych zawodowo inżynierom, ekspertom podnosi jakość oferty. Natomiast brak monitoringu losów absolwentów studiów podyplomowych nie pozwala na weryfikację zakładanych efektów kształcenia, na poznanie uwarunkowań wpływających na zgodność oferty edukacyjnej z potrzebami rynku pracy, na poznanie realnych korzyści dla pracownika - absolwenta studiów i rozwoju przedsiębiorstwa, w którym pracuje. Wysoka jakość oferty studiów podyplomowych, a w szczególności taka jej cecha jak dostosowanie do potrzeb rynku pracy, będzie miała istotne znaczenia, gdyż ta forma kształcenia może stanowić kluczową ofertę w całej ofercie dydaktycznej uczelni w Polsce z uwagi na prognozy demograficzne ${ }^{17}$. I tak do 2023 roku przewiduje się, że liczba osób w wieku 19 lat (a więc kandydatów na studia) do roku 2035 będzie poniżej 350 tys. w porównaniu do 450 tys. w 2014 roku i 550 tys. w $2009 \mathrm{roku}^{18}$. Uczelnie zatem będą musiały szukać innych grup docelowych - studentów/uczestników studiów podyplomowych.

Ponadto zmiany na rynku pracy, postęp techniczny zmusza pracowników do podnoszenia (nawet zdobywania nowych/innych) kompetencji przez całe życie zawodowe, zgodnie z filozofią Lifelong Learning - uczenia się przez całe życie, co stwarza zapotrzebowania na uczestnictwo w studiach podyplomowych i różnych innych formach kształcenia.

\section{BIBLIOGRAFIA:}

Budrowska, B., „Szklany sufit”, czyli co blokuje kariery kobiet, Kultura i Historia nr 6/2004.

Dane Eurostat za 2014 rok. http://ec.europa.eu/eurostat/tgm/table.do?tab=table\&plugin=1\&language $=$ en $\&$ p code $=$ tsdsc 440

Dziedziczak-Foltyn, A., Lifelong learning jako niedoceniania w Polsce droga do społeczeństwa wiedzy, Serwis HR, Wolters Kluwer 2015.

Frąckiewicz L., Rączaszek A. (red.) Kapitat Społeczny, Katowice 2004.

Grotowska-Leder J., Rzecz o ksztatceniu dorostych. Lifelong learning w Polsce, w perspektywie Unii Europejskiej, ACTA UNIVERSITATIS LODZIENSIS, FOLIA SOCIOLOGICA 50, 2014 http://syntea.pl/media/materialy/Syntea_przedsiebiorstwa.pdf.

${ }^{16}$ Żadna z powyższych rekomendacji nie była przewidziana jako warunek koniczny czy nawet pożądany w ramach Regulaminów dotyczących uruchomiania studiów podyplomowych na uczelniach, które brały udział w daniu własnym.

${ }^{17}$ Kujawska J., Szuwarzyński, A., Studia podyplomowe w świetle zaleceń Europejskich Ram Kwalifikacji, „E-mentor” nr 5 (32) / 2009; http://www.e-mentor.edu.pl/artykul/index/numer/32/id/698; (dostęp 15.05.2016); A. Marcinkiewicz, Kształcenie podyplomowe wobec rynku pracy, E-mentor, 2012, nr 2, s. 54-60, http://www.e-mentor.edu.pl/artykul/index/numer/44/id/922, (dostęp 16.05.2016).

18 Dane GUS. 
Janiak-Rejno, I. Kształcenie ustawiczne stuchaczy studiów podyplomowych - wyniki badań empirycznych, „Edukacja ustawiczna dorosłych” 2009, nr 4(67).

Kujawska J., Szuwarzyński, A., Studia podyplomowe w świetle zaleceń Europejskich Ram Kwalifikacji, „E-mentor” nr 5 (32) / 2009;

Marcinkiewicz, A., Kształcenie podyplomowe wobec rynku pracy, E-mentor, 2012, nr 2.

Poteralski, J., Ogólnopolskie badania na grupie osób odpowiedzialnych za studia podyplomowe, Szczecin, czerwiec 2013.

Raport Agencji Wykonawczej ds. Edukacji, Kultury i Sektora Audiowizualnego (EACEA), Dorośli w systemie edukacji formalnej: polityka i praktyka w Europie, tłum. J. Czernik, Fundacja Rozwoju Systemu Edukacji, Warszawa 2011.

Raport „Kobiety na politechnikach 2016”, Fundacja Edukacyjna Perspektywy, Marzec 2016. http:// dziewczynynapolitechniki.pl/2015/images/dla-mediow/raport-kobiety-napolitechnikach-2016. pdf; (dostęp 16.05.2016).

Rozporządzenie MNiSW z 2.11.2011r. w sprawie KRK dla Szkolnictwa Wyższego, D.U.11.253.1520 Szkoty wyższe i ich finanse, GUS 2008-2014.

Ustawa z dnia 27 lipca 2005 r. - Prawo o szkolnictwie wyższym; Dz.U. nr 164, poz. 1365 z późn. zm.

\section{Streszczenie}

Artykuł przedstawia charakterystykę i analizę studiów podyplomowych w Polsce jako formę kształcenia ustawicznego, a także opisuje wyniki badań autora dotyczących organizowania studiów podyplomowych przez uczelnie techniczne. W ramach badań dokonuje się próby określenia czynników warunkujących zgodność oferty edukacyjnej uczelni (lub jednostek naukowych posiadających uprawnienia do ich prowadzenia) z potrzebami rynku pracy, stymulującej rozwój i efektywność gospodarki (realne korzyści dla rozwoju przedsiębiorstw) oraz zaspokojenie dążeń pracodawców i pracowników do podnoszenia kwalifikacji zawodowych. W konkluzjach stwierdza się, że studia podyplomowe będą zajmowały kluczową pozycję na rynku edukacyjnym w ramach LLL.

Słowa kluczowe: studia podyplomowe, kształcenia ustawiczne, LLL, dostosowanie oferty edukacyjnej do potrzeb rynku pracy.

\section{POSTGRADUATE STUDIES AT UNIVERSITIES OF TECHNOLOGY - EDUCATIONAL OF- FER ADJUSTMENT TO THE LABOUR MARKET NEEDS}

Sum mary

The article examines the description and analysis of postgraduate programmes in Poland delivered as part of the continuing education process. Furthermore, the author of this article presents findings of his research on technical higher education institutions offering postgraduate programmes. Factors determining whether courses of study offered in a certain higher education institution (or academic units authorised to delivering such courses) meet current needs demonstrated on the labour market, stimulate development and effective functioning of the economy (factual benefits for development of companies) and satisfy expectations held by employers and employees willing to increase their 
professional skills. In the summary it is concluded that postgraduate programmes will be playing the key role on education market within life-long learning.

Keywords: Postgraduate studies, Lifelong Learning, educational offer adjustment to the labour market needs. 